\title{
コリオリカを用いた動吸振器による索道搬器の制振*
}

\author{
松 久 寛*1, 宇津野 秀夫*1, 磯 野 充 典*2
}

\section{Dynamic Absorber for Ropeway Gondola using Coriolis Force}

\author{
Hiroshi MATSUHISA*3, Hideo UTSUNO and Mitsunori ISONO \\ ${ }^{* 3}$ Department of Mechanical Engineering, Kyoto University, \\ Yoshida-Honmachi, Sakyo-ku, Kyoto-shi, Kyoto, 606-8501 Japan
}

\begin{abstract}
The swing of a ropeway gondola is easily induced by wind and can be reduced by a dynamic absorber. To maxmize the performance of conventional dynamic absorber, their location should be as high as possible. However, absorbers can not be located at high positions due to interference issues with structures such as towers and stations. To solute this problem, a new type dynamic absorber is proposed in this paper. It reduces a swing of gondola, by making use of Coriolis force which moves in the radical direction. This absorber is more effective when it is located at lower position. The damping force of conventional absorber is proportional to the amplitude of the vibration of main mass, however, the Coriolis force is proportional to the cube of amplitude. Therefore, it is more effective when the amplitude of gondola is larger.
\end{abstract}

Key Words: Vibration Control Device, Dynamic Absorber, Coriolis Force, Pendulum, Ropeway Carrier

\section{1. 緒 言}

索道 (ロープウェー) は現在, 多くのスキー場や観 光地で使用されている. また, 高い輸送力と鉄道に比 べて安価な建設コストという長所があるため将来の都 市交通の手段として期待されている. しかし, ジンド ラなどの搬器の横摇れは, 減衰が非常に小さく, 風で 容易に励起されるという短所があり，スキー場などで は風速 $15 \mathrm{~m} / \mathrm{s}$ ぐらいで運休を余儀なくされている. 索 道搬器はその構造上, 减衰を大きくすることは難しく, その制振手段としてはジャイロモーメントを利用する 方法 ${ }^{(1)}$ と動吸振器を使う方法(2)が提案されている.

外部からのエネルギ一供給やセンサ, アクチュエー 夕, 制御装置を必要としない動吸振器は索道搬器に適 しており，円軌道型動吸振器は既に実用化されている. 松久らの研究(2)によれば, 円軌道型動吸振器はゴンド ラの重心位置（正確にはゴンドラは剛体振子であるの で振動の中心）から離れた位置に取り付けるほど制振 効果が大きくなり, 重心に取り付けると全く効果がな い. 従って, 実際に円軌道型動吸振器を取り付ける際 には，できるだけゴンドラの上部に取り付ける必要が

\footnotetext{
* 原稿受付 2006 年 4 月 6 日.

*1 正員. 京都大学工学研究科(画606-8501 京都市左京区吉田 本町).

*2 三菱重工業(株) 高砂研究所(画678-8686 高砂市荒井町新浜 2-1-1).

E-mail : matsu@me.kyoto-u.ac.jp
}

ある ${ }^{(3)}$. しかし, 実用上は支柱や駅舎と動吸振器との 衝突を避ける等の理由から, 動吸振器をあまり上部に は取り付けられない.

そこで, 取り付け位置の問題を解決するため, 本研 究ではコリオリカを利用した動吸振器を提案し, これ をコリオリ型動吸振器と称す.これは振り子の半径方 向に運動する質量によって生じるコリオリカで制振す る. コリオリ型動吸振器の動作原理を解析し, 特性お よび最適な設計法を理論解析および実験から求める.

なお, 付加質量を半径方向に動かして, 円周方向の 制振をするというメカニズムはゴンドラのみならず, 他の対象においても，内外の文献には見当たらない．

\section{2. 理論解析}

$2 \cdot 1$ 通動方程式 図1に示すように, ゴンドラ を 1 自由度の単振子とする. 質量を $m_{1}$, 支点 0 から 重心 $G$ までの距離を $l_{1}$, 角変位を $\theta$ とする. ここで, 主系には角速度に比例する減衰が働くとし，その減衰 係数を $c_{1}$ とする. コリオリ型動吸振器は静止時の質量 中心が支点O から距離 $l$ の位置になるように取り付け られ, 半径方向に直線運動寸るとし, その変位を $u$ と する. また, 質量を $m_{2}$, ばね定数を $k$, 減衰係数を $c$ とする. 支点Oを原点として $x y$ 座標を図のように水 平および鉛直方向に取ると, ゴンドラの重心位置 


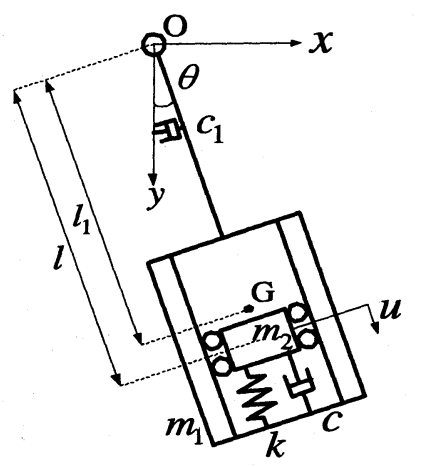

Fig. 1 Coriolies absorber on a gondora.

$\left(x_{1}, y_{1}\right)$ と動吸振器の質量の位置 $\left(x_{2}, y_{2}\right)$ は,

$$
\begin{aligned}
& x_{1}=l_{1} \sin \theta \\
& y_{1}=l_{1} \cos \theta \\
& x_{2}=(l+u) \sin \theta \\
& y_{2}=(l+u) \cos \theta
\end{aligned}
$$

となる.これより，両者の速度は次式で与えられる.

$$
\begin{aligned}
& \dot{x}_{1}=l_{1} \dot{\theta} \cos \theta \\
& \dot{y}_{1}=-l_{1} \dot{\theta} \sin \theta \\
& \dot{x}_{2}=(l+u) \dot{\theta} \cos \theta+\dot{u} \sin \theta \\
& \dot{y}_{2}=-(l+u) \dot{\theta} \sin \theta+\dot{u} \cos \theta
\end{aligned}
$$

主系およひ動吸振器の運動エネルギーの総和 $T$ は

$$
T=\frac{1}{2} m_{1} l_{1}^{2} \dot{\theta}^{2}+\frac{1}{2} m_{2}\left[(l+u)^{2} \dot{\theta}^{2}+\dot{u}^{2}\right]
$$

となり, 位置エネルギーの総和 $V$ は, 静止時を基淮に 取り, 重力加速度を $\mathrm{g}$ とすると,

$$
\begin{aligned}
V & =m_{1} g l_{1}(1-\cos \theta)+m_{2} g(l+u)(1-\cos \theta) \\
& +\frac{1}{2} k u^{2}
\end{aligned}
$$

となる. 散逸関数 $\boldsymbol{F}$ は,

$$
F=\frac{1}{2} c_{1} \dot{\theta}^{2}+\frac{1}{2} c \dot{u}^{2}
$$

となる. これらより, 加振力 $P e^{j \omega t}$ が重心に働くとし たとき, 運動方程式は, 次の二式となる.

$$
\begin{aligned}
& m_{1} l_{1}^{2} \ddot{\theta}+m_{2}(l+u)^{2} \ddot{\theta}+c_{1} \dot{\theta}-2 m_{2}(l+u) \dot{u} \dot{\theta} \\
& +\left[m_{1} g l_{1}+m_{2} g(l+u)\right] \sin \theta=P l_{1} \mathrm{e}^{\mathrm{j} \omega t} \\
& m_{2} \ddot{u}+c \dot{u}+k u-m_{2}(l+u) \dot{\theta}^{2} \\
& +m_{2} g(1-\cos \theta)=0
\end{aligned}
$$

式(12)の第4 項のコリオリカ $2 m_{2} \dot{u} \dot{\theta}$ が円周方向の制 振力として働く. また, 式(13)の第4 項 $m_{2}(l+u) \dot{\theta}^{2}$ は 遠心力, 第 5 項 $m_{2} g(1-\cos \theta)$ は動吸振器に加わる重 力の半径方向成分であり, これらが動吸振器を半径方 向に加振する力として働く.

$2 \cdot 2$ 最商設計 動吸振器を取り付けた単振子の 等価な腕の長さを $l_{\mathrm{e}}$, 固有振動数を $\omega_{1}$, 動吸振器の固 有振動数を $\omega_{\mathrm{a}}$ とすると, これらは以下の式で与えら れる.

$$
l_{\mathrm{e}}=\frac{m_{1} l_{1}^{2}+m_{2} l^{2}}{m_{1} l_{1}+m_{2} l}
$$

$$
\omega_{1}=\sqrt{\frac{g}{l_{\mathrm{e}}}} \quad(15) \quad \omega_{\mathrm{a}}=\sqrt{\frac{k}{m_{2}}}
$$

ここで, 以下の無次元量を導入する.

$$
\begin{aligned}
& \mu=\frac{m_{2}}{m_{1}}, \quad \gamma=\frac{l}{l_{1}}, \quad f=\frac{\omega_{\mathrm{a}}}{\omega_{1}}, \quad h=\frac{\omega}{\omega_{1}} \\
& \zeta_{1}=\frac{c_{1}}{2 m_{1} l_{\mathrm{e}}^{2} \omega_{1}}, \quad \zeta=\frac{c}{2 m_{2} \omega_{1}}, \quad \Theta_{\mathrm{st}}=\frac{P}{m_{1} g}
\end{aligned}
$$

本研究で提案するコリオリ型動吸振器の設計パラ メータとしては質量比 $\mu$, 取り付け位置比 $\gamma$, 振動数 比 $f$, 减衰比 $\zeta$ があ. これらの值と制振効果の関係 を調へ，最適な振動数比 $f$, 減衰比 $\zeta$ 求める.

従来の線形な動吸振器の設計では，定点理論を用い ることにより最適化を行う.しかし，運動方程式(12), (13)は非線形であり，本研究で提案するコリオリ型動 吸振器は従来のような定点理論による最適設計ができ

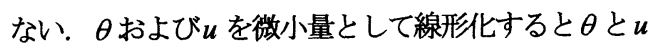
が連成せず，単に振り子の質量 $m_{1}$ に質量 $m_{2}$ を付加し たことを意味する. しかし， $\theta$ おびいの高次項まで 考慮すると, 運動方程式(12), (13)から振動数比の最適 値について次のような推論ができる. 動吸振器の制振 効果を高めるためには，主系が加振されたときの動吸 振器の振幅をできるだけ大きくし，一周期あたりのエ ネルギー吸収量を大きくすればよい. 式(13)の第 4 項 の遠心力および第 5 項の重力の半径方向成分の変動が コリオリ型動吸振器の加振力として働いており, 動吸 振器は主系の 2 倍の振動数で加振される. 従って, 動 吸振器の固有振動数を主系の 2 倍に設定すれば動吸振 器の振幅は共振で大きくなる. つまり, 最適な振動数 比 $f$ は 2 付近に存在する.

運動方程式(12), (13)より求めた周波数応答のピーク 值を最小化するような振動数比 $f$ と減衰比 $\zeta$ を数值 
解析的に探索した. ここで, 主系の諸元は実際の 12 人乗りのゴンドラを想定して $m_{1}=790 \mathrm{~kg}, l_{1}=3.8 \mathrm{~m}$, $\zeta_{1}=0.005$ とした. 以下の理論解析において主系の諸 元は基本的にこの值を用いる. 振動数比と減衰比を $1.95 \leq f \leq 2.05,0 \leq \zeta \leq 0.15$ の範囲で変化させたと きの各周波数応答の最大振幅值を図 2 に示す.

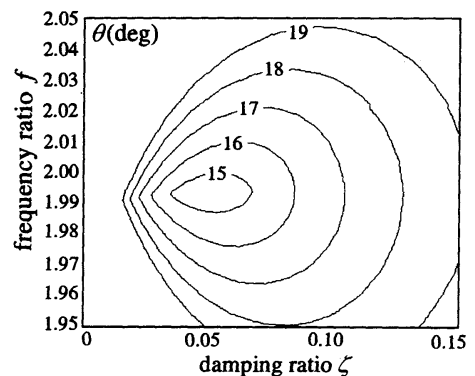

(a) $\mu=0.1, \gamma=1, \Theta_{\mathrm{st}}=0.01$

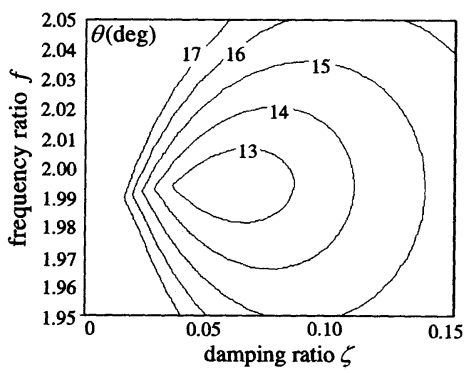

(b) $\mu=0.2, \gamma=1, \Theta_{\mathrm{st}}=0.01$

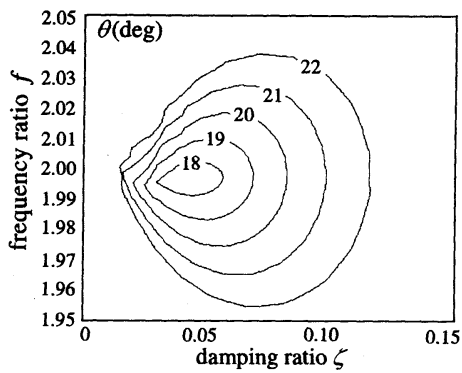

(c) $\mu=0.1, \gamma=0.5, \Theta_{\mathrm{st}}=0.01$

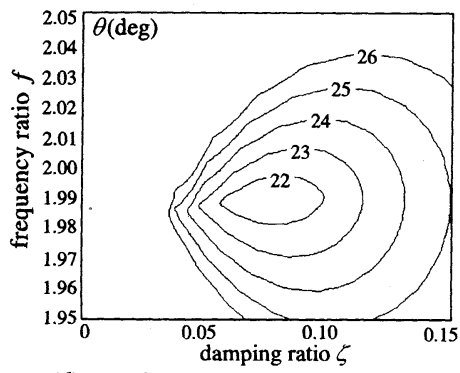

(d) $\mu=0.1, \gamma=1, \quad \Theta_{\mathrm{st}}=0.02$

Fig. 2 Contour lines of maximum amplitude. 同図(a)は標準的なパラメータ $\mu=0.1, \gamma=1$, $\Theta_{\mathrm{st}}=0.01$ とし, 同図(b)は動吸振器の質量を $\mu=0.2$ と大きくしたとき, 同図(c) は動吸振器の位置を $\gamma=0.5$ と上部にしたとき, 同図(d) は加振力を $\Theta_{\mathrm{st}}=0.02$ と 2 倍にしたときである. これより質量比 $\mu$, 取り付け位置 $\gamma$, 無次元化外力 $\Theta_{\mathrm{st}}$ に関わらず, 振動数比の最適值は $f=2$ より少し小さい1.99近傍に 存在することが分かる. 最適振動数比が 2 よりわずか に小さいのは減衰の影響である. また減衰比 $\zeta$ の最適 值は 0.05 0.1 付近に存在する. 同図(c)より, 取り付 け位置が上部になると動吸振器の効果が堿少し, ゴン ドラの振幅が大きくなる. 同図 2(d)のように加振力が 大きく，振幅が大きいときには最適堿衰比も大きくな る.

$2 \cdot 3$ 周波数応答 $\quad$ 動吸振器の諸元を $\mu=0.1$, $\gamma=1, f=1.99, \Theta_{\mathrm{st}}=0.015$ としたときの周波数 応答を図 3 に示す. 動吸振器により共振のピークが約 $1 / 2$ に抑えられている. 減衰比 $\zeta=0.06$ が一番制振効 果は高い. しかし, 動吸振器の質量自体は $\zeta=0.03$ の ときの方が大きく振動している.これは動吸振器の工 ネルギー吸収は $\zeta=0.06$ のときが大きいからであり, 減衰比に最適值が存在することが分かる.
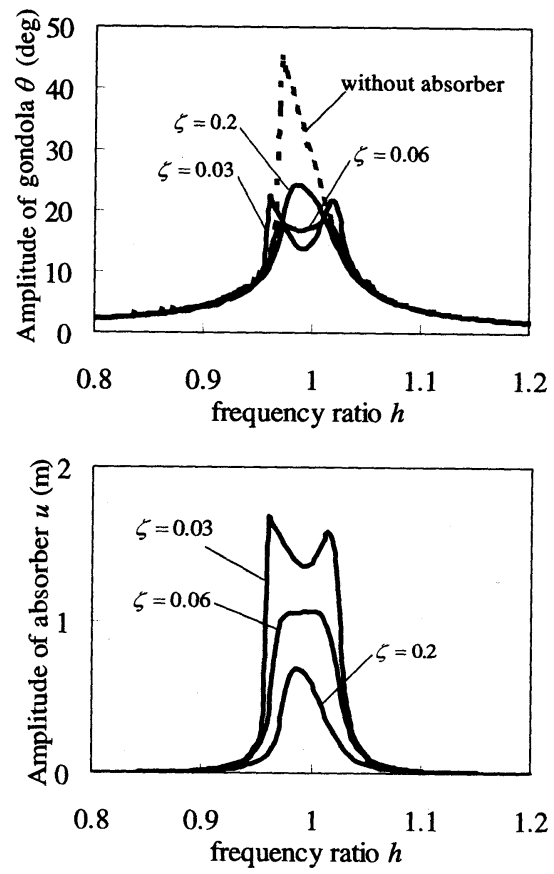

Fig. 3 Frequency responses for various damping ratios. 
$2 \cdot 4$ 自由応答 動吸振器の諸元を $\mu=0.1$, $f=2, \gamma=1, \zeta=0.06$ とし, 初期角度 30 度から自 由振動させたときの主系および動吸振器の自由応答の 理論計算結果を図 4 に示す. 動吸振器により, 減衰が 大きくなっている. また, 動吸振器は主系の二倍の振 動数で振動しており, その振動が十分励起されるのに 数周期必要であることが分かる.
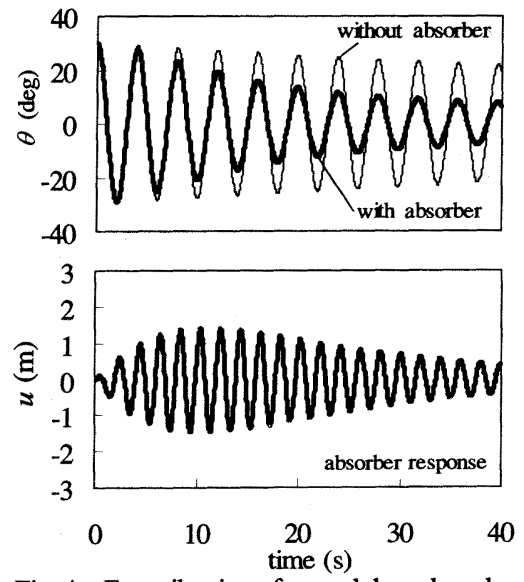

Fig. 4 Free vibration of a gondola and an absorber.

$2 \cdot 5$ ランダム応答 模擬的な風外力を主系に 加えたときの応答を数值計算で求める. 動吸振器の 諸元は $\mu=0.1, \gamma=1, f=2, \zeta=0.06$ とする. 風外力は Davenport の式吕用いて作成した. 風速 $20 \mathrm{~m} / \mathrm{s}$ の風外力の一例を図 5 に示す. 風速 $15 \mathrm{~m} / \mathrm{s}$, $20 \mathrm{~m} / \mathrm{s}, 25 \mathrm{~m} / \mathrm{s}$ の模擬的な風外力を主系に加えたとき の主系の時間応答をそれぞれ図6に示した. これよ り, 風のようなランダムな外力に対しても, 動吸振 器が有効であることが確認できる. また風速が強い ほど動吸振器の制振効果がより高いことが確認で きる. 風速 $25 \mathrm{~m} / \mathrm{s}$ では, 動吸振器により摇れは $2 /$ 3 程度に抑えられている. しかし, 風速 $15 \mathrm{~m} / \mathrm{s}$ では, 動吸振器の効果はほとんどない.

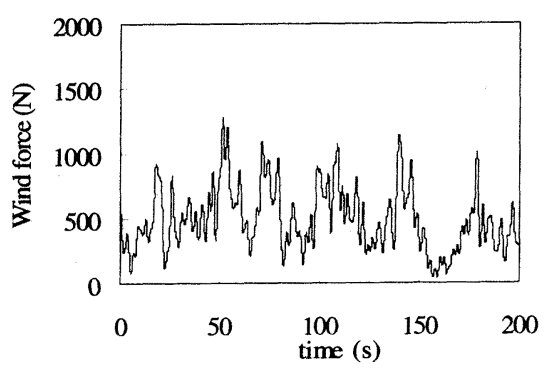

Fig. 5 Simulated wind force.
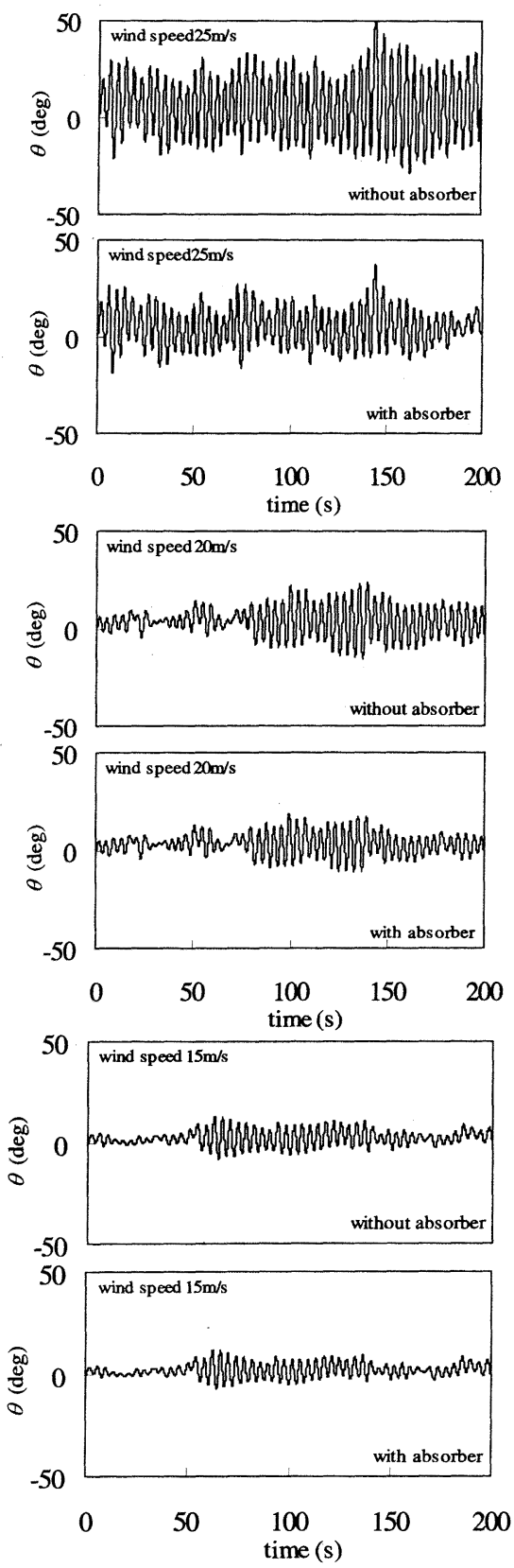

Fig. 6 Time response of a gondola excited by wind force.

2-6 動吸振器の振幅依存性線形な動吸振器にお いては動吸振器の制振効果は質量比のみに依存し, 加 振力や主系振幅に依存しない.これに対し, 本研究で 提案するコリオリ型動吸振器は非線形な動吸振器なた め, 制振効果が加振力や主系振幅に依存する. コリオ リ型動吸振器の取り付け位置比を $\gamma=1$, 質量比を $\mu=0.05,0.1,0.2$ とした場合の加振力と主系の周波 
数応答の最大值の関倸 $\Theta_{\text {max }} / \Theta_{\mathrm{st}}$ を図 7(a)に示す. また 動吸振器の質量比を $\mu=0.1$, 取り付け位置比を $\gamma=0$, $0.5,1$ とした場合の加振力と主系の周波数応答の最大 值の関係を図 7(b)に示す. ただし, 動吸振器の振動数 比, 减衰比は各加振力において数值解析的に探索した 最適值を用いた. 線形な動吸振器の場合, 加振力に関 わらず周波数応答 $\Theta / \Theta_{\mathrm{st}}$ は一定であるが, コリオリ型 動吸振器の場合, 加振力が大きくなるにしたがい周波 数応答の最大值は急速に小さくなっている. 質量比 $\mu$ が大きくなると，制振効果は增加する．また，動吸振 器を下に取り付ける $(\gamma$ : 大)ほど制振効果は大きい.

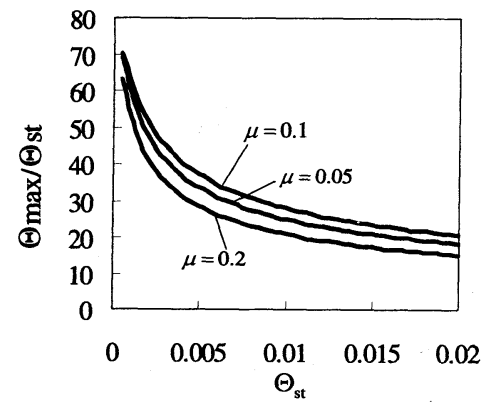

(a) $\gamma=1$

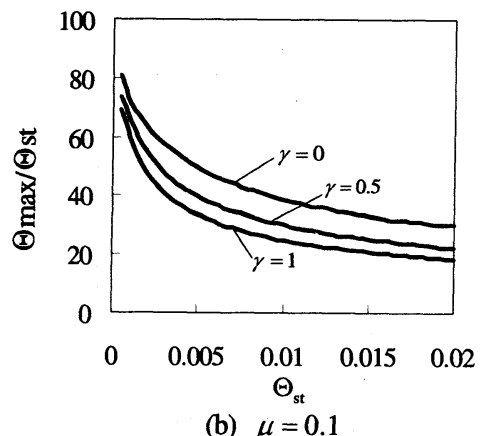

Fig. 7 Maximum value of frequency response as a function of $\Theta_{\text {st }}$.

コリオリカと主系振幅の大きさの関倸について以下 のように説明できる. コリオリ型動吸振器の加振力と しては式(13)の第4 項の遠心力 $m_{2}(l+u) \dot{\theta}^{2}$ と同第 5 項 の動吸振器に加わる重力の半径方向成分 $m_{2} g(1-\cos \theta)$ がある. 遠心力は主系の振幅の二乗に 比例する. また主系の振幅が小さいとき, 動吸振器に 加わる重力の半径方向成分 $m_{2} g(1-\cos \theta)$ は $(1 / 2) m_{2} g \theta^{2}$ で近似され，これも主系の振幅の二乗に 比例する. したがって, 動吸振器の振幅 $u$ は主系の振 幅の二乗に比例することになる. コリオリカは式(12)
の第 4 項 $2 m_{2} \dot{u} \dot{\theta}$ で与えられるため, 結局, 本研究で 提案する動吸振器の制振力は主系の振幅のほぼ二乗に 比例する.

\section{$2 \cdot 6$ 取り付け位置による影霎 $\quad \mu=0.1$,} $\Theta_{\mathrm{st}}=0.015$ とし, 動吸振器の取り付け位置を $\gamma=0$, $0.5,1$ と変えた場合の周波数応答を図 8 に示す. ただ し, 動吸振器の振動数比 $f$, 減衰比 $\zeta$ は数值解析的に 探索した最適値を用いている. それぞれ最適值は表 1 に示した. この図およひ図 7(b)より, 取り付け位置が 支点から離れるほど制振効果が大きいことが分かる. この理由としては, 取り付け位置が支点から離れるほ ぞ, 動吸振器を加振する遠心力が大きくなるため, 動 吸振器が大きく振動し, さらに主系に加わるコリオリ カによる制振モーメントの腕の長さが長くなるためで， ある.

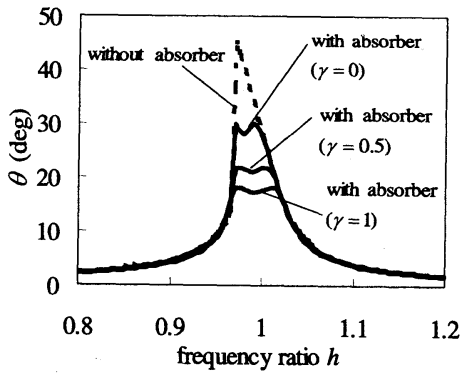

Fig. 8 Frequency response for three mass locations.

Table 1 Calculated optimal value $f$ and $\zeta$.

\begin{tabular}{c|c|c}
\hline \hline$\gamma$ & $f$ & $\zeta$ \\
\hline 0 & 1.989 & 0.034 \\
\hline 0.5 & 1.994 & 0.054 \\
\hline 1 & 1.992 & 0.064 \\
\hline
\end{tabular}

\section{3. 実験}

$3 \cdot 1$ 実験装置 実験に用いた動吸振器の力学モ デルを図 9 に, 写真を図 10 に示す. 主系は単振子で水 平移動する加振台に取り付けられている. その写真を 図 11 に示す. 振り子に加振モーメントを加える代わり に, 加振台を左右に振動させて, 振り子の支点に強制 変位 $x_{0}$ を与える. 動吸振器の質量は左右の $\Lambda$ 字型のガ イドからばねで支えており、ばね端は $\Lambda$ 字型のガイド 上を滑らかに移動するリニアベアリングにつながって いる. また動吸振器には軸が通してあり, 動吸振器の 運動を半径方向のみに拘束している. 動吸振器の運動 
方向とガイドのなす角度を $\alpha$ とすると, 半径方向のみ かけのバネ定数は $k \sin ^{2} \alpha$ となり, 角度 $\alpha$ により動吸 振器の周期の調整が可能となっている. 動吸振器には 磁石が取り付けられており動吸振器が運動したとき, 磁石とアルミニウム製の板との間に発生する渦電流を 利用して減衰力を得ている. 減衰の大きさは磁石の数 で調整している．本実験における実験機の諸元は $m_{1}=2.54 \mathrm{~kg}, l_{\mathrm{e}}=0.69 \mathrm{~m}, \mu=0.23, \gamma=1, f=2.0$, $\zeta=0.07$ である.

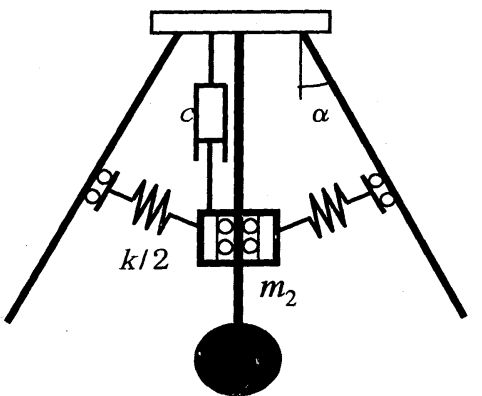

Fig. 9 Model of experimental Coriolis dynamic absorber.

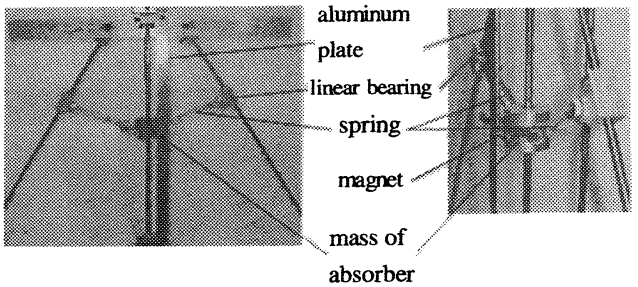

Fig. 10 Picture of Coriolis dynamic absorber.

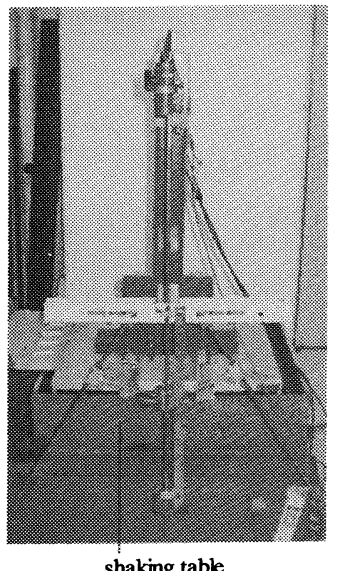

Fig. 11 Picture of experimental apparatus.

3 -2 実験結果 周波数応答の測定結果を図 12 に○印で示す. 加振振幅は $8 \mathrm{~mm}$ である. 理論計算結 果と同様に共振のピークはよく制振されている. 初期
変位 25 度からの自由振動を図 13 に示す.主系振幅が 大きい領域では動吸振器による减衰が大きくなってい るのに対し，主系振幅の小さい領域において，その効 果が小さくなっていることが確認できる. ランダム応 答を図 14 に示す.なお, 同図の上段は加振変位である. 動吸振器によって振幅は約 23 になっている.

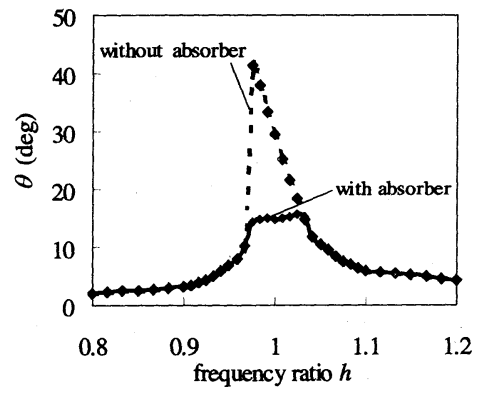

Fig. 12 Experimental results of frequency response.

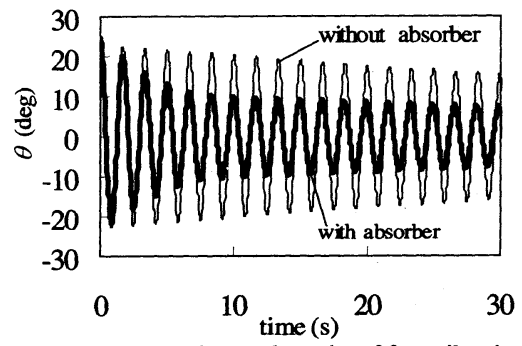

Fig. 13 Experimental results of free vibration.

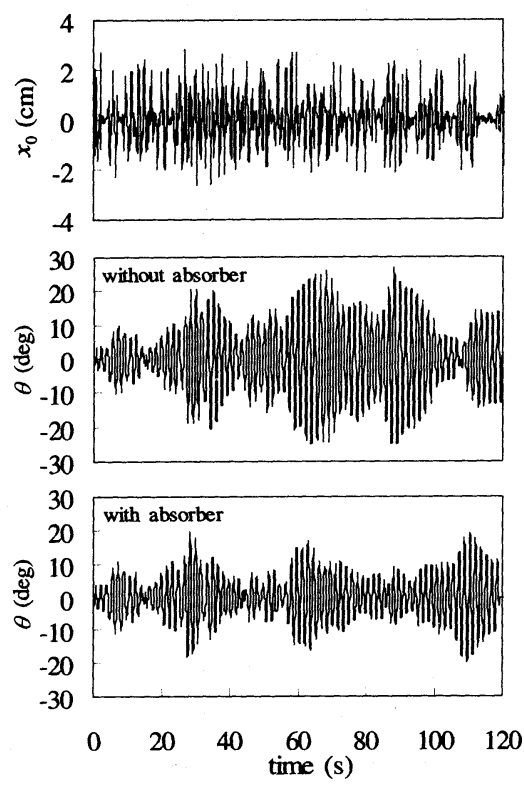

Fig. 14 Experimental results of random response. 
動吸振器の取り付け位置を $\gamma=1$ と 0.41 としたとき の周波数応答の実駼結果を図 15 に示す. ただし, 他の 諸元は $\mu=0.23, f=2.0, \zeta=0.07$ である. 取り付 け位置による制振効果の差がよく表れれいる.

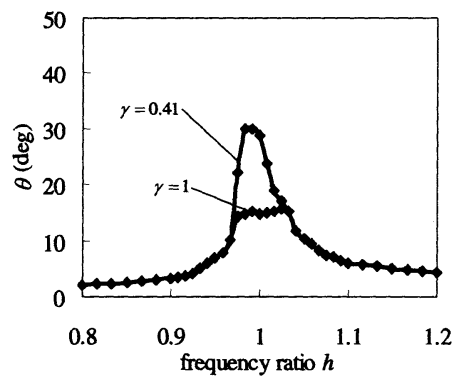

Fig. 15 Experimental results of frequency response.

これらの実験結果より, コリオリ型動吸振器の制振 効果が実証され, 制振効果の振幅依存性や取り付け位 置依存性が確認された。

\section{4. 結言}

本研究ではゴンドラの重心位置近傍に取り付けた際 にも制振効果を得られる動吸振器の開発を目的として, 振り子の半径方向に運動する新しい構造の動吸振器を 提案した. この動吸振器は, 遠心力を起振力とし, 半 径方向に運動する際に生じるコリオリカで制振する. 動吸振器の取り付け位置を支点から離すほど制振効果 が高いので, 従来型の動吸振器では効果がない主系の 重心位置に取り付けた際にも制振効果があることを確 認できた. また，本研究で提案する動吸振器には振幅 依存性があり，主系振幅が小さいときにはあまり效果 がなく，主系振幅が大きくなるほど制振効果が高くな る.これは，制振力として働いているコリオリカが主 系振幅の三乗にほぼ比例するためである. 従って, 実 際にこの動吸振器を用いる際には，主系の大振幅をあ る程度の大きさの振幅まで落とす目的で使用すること が考えられる.

なお，本研究で提案した制振メカニズムはゴンド ラのみならず，振幅の大きい回転振動には適用可能で ある.

\section{文献}

(1) Nishihara O, et al., Vibration Damping with Gyroscopic Moments, Transactions of the Japan Society of Mechanical Engineers, Series C, 57-534, (1991), pp.497-503.
(2) Matsuhisa H., et al, Vibration Control of a Ropeway Carrier by Passive Dynamic Vibration Absorbers, Transactions of the Japan Society of Mechanical Engineers, Series C, Vol. 38, No. 4, (1995), pp. 657-662.

(3) Matsuhisa H. and Yasuda M.., Location effect of dynamic absorbers on rolling structures, Proceedings of the Asia-Pacific Vibration Conference, (2003), pp.439-444.

(4) Davenport A. G., The Spectrum of Horizontal Gustiness Near the Ground in High Winds, Quarterly Journal of the Royal Meteorological Society, Vol.87, (1961), pp.194-211. 